Куртакова Анна Олександрівна доктор філософії в галузі права, доцент кафедри цивільного та господарського права Інституту права ім. князя Володимира Великого, Міжрегіональна Академія управління персоналом, м. вул. Фрометівська, 2, Київ, 03039, тел.: (050) 264-00-30, e-mail: anita-k@ukr.net, https:/orcid.org/0000-0002-9475-6911

Передільчук Аліна Сергіївна магістр психології, Міжрегіональна Академія управління персоналом, вул. Фрометівська, 2, м. Київ, 03039, тел.: (067) 722-76-11, e-mail: alin4ik94@ukr.net, https://orcid.org/0000-0001-6379-7967

\title{
ОСОБЛИВОСТІ МІЖОСОБИСТІСНИХ ВІДНОСИН У ПЕДАГОГІЧНОМУ КОЛЕКТИВІ
}

Анотація. В епоху значних досягнень науки і техніки, епоху загальної інформатизації та комп'ютеризації, особливо гостро відчувається потреба особистості в успішної професійної самореалізації. А.С. Рубінштейн писав: «У глибині душі ми жадаємо корисного, творчої праці, що дає поживу розуму i справу для рук, - праці, що відповідає найпомітнішим нашим устремлінням ... У ритмі вільного обраного і виконуваного з задоволенням праці укладено секрет розуміння і цілі життя» [1]. Діяльність справжнього професіонала включає в себе компоненти наукової компетентності та прояв чеснот. Проявити себе всебічно в роботі він може лише при активній взаємодії з колегами і керівництвом в процесі міжособистісних відносин. А відносини - це цілісна система індивідуальних, виборчих, свідомих зв'язків особистості з різними сторонами об'єктивної дійсності, що включає три взаємопов'язані компоненти: ставлення людини до людей, до себе, до предметів зовнішнього світу. Міжособистісні стосунки у педагогічному колективі, які охоплюють широкий діапазон явищ, можуть бути класифіковані з урахуванням таких компонентів взаємодії, як сприйняття й розуміння людьми одне одного; міжособистісна привабливість (тяжіння й симпатія); взаємовплив і поведінка (рольова). На думку Я.Л. Коломінський міжособистісні відносини як «... особистісно значуще образне емоційне і інтелектуальне відображення людьми один одного, яке представляє собою їх внутрішній стан» [2]. Стосовно психологічного словника під редакцією А.В. Петровського i М.К. Ярошевського поняття «міжособистісні відносини» розкривається як система установок, орієнтацій і очікувань членів групи відносно один одного, обумовлених змістом спільної діяльності і цінностями, на яких грунтується спілкування людей [3]. Обидва ці визначення дозволяють зробити висновок, що міжособистісні відносини в педагогічному колективі - це взаємні орієнтації, які розвиваються і шліфуються у людей, що знаходяться в тривалому контакті, в процесі спільної освітньої діяльності. 
Ключові слова: міжособистісних відносин, педагогічний колектив, мотивація, конфлікти.

Kurtakova Anna Alexandrovna Doctor of Philosophy in Law, Associate Professor of Civil and Commercial Law, Institute of Law. Prince Vladimir the Great, Interregional Academy of Personnel Management, Frometivska St., 2, Kyiv, 03039, tel.: (050) 264-00-30, e-mail: anita-k@ukr.net, https: /orcid.org/0000-0002-9475-6911

Peredilchuk Alina Sergeevna Master of Psychology, Interregional Academy of Personnel Management, Frometivska St., 2, Kyiv, 03039, tel .: (067) 722-76-11, e-mail: alin4ik94@ukr.net, https://orcid.org/0000-0001-6379-7967

\title{
PECULIARITIES OF INTERPERSONAL RELATIONS IN THE TEACHING TEAM
}

\begin{abstract}
In the era of significant achievements of science and technology, the era of general informatization and computerization, the need of the individual for successful professional self-realization is especially acute. A.S. Rubinstein wrote: "Deep down we crave useful, creative work that nourishes the mind and work for the hands - work that meets our most visible aspirations ... In the rhythm of free choice and work performed with pleasure is the secret of understanding and purpose of life".

The activities of a true professional include components of scientific competence and the manifestation of virtues. He can show himself fully in the work only with active interaction with colleagues and management in the process of interpersonal relationships. And the relationship is a holistic system of individual, selective, conscious connections of the individual with various aspects of objective reality, which includes three interrelated components: a person's attitude to people, to himself, to the objects of the external world. Interpersonal relationships in the teaching staff, which cover a wide range of phenomena, can be classified taking into account such components of interaction as people's perception and understanding of each other; interpersonal attractiveness (attraction and sympathy); interaction and behavior (role). According to Ya.L. Kolominsky interpersonal relationships as "... personally significant figurative emotional and intellectual reflection of each other, which is their inner state." [7, p.110] Regarding the psychological dictionary edited by A.V. Petrovsky and MK Yaroshevsky's concept of "interpersonal relations" is revealed as a system of attitudes, orientations and expectations of group members towards each other, due to the content of joint activities and values on which human communication is based. [6, p.263]. Both of these definitions allow us to conclude that interpersonal relationships in the teaching staff are mutual orientations that develop and are refined in people who are in longterm contact in the process of joint educational activities.
\end{abstract}

Keywords: interpersonal relations, pedagogical collective, motivation, conflicts.

Постановка проблеми. Сучасний педагог одночасно виконує функції викладача, класного керівника (вихователя), керівника гуртка та громадського 
діяча. Вирішуючи професійні завдання, педагогічний колектив виходить за рамки навчального закладу: формує педагогічну культуру батьків і суспільства в цілому. Основні питання життя i діяльності педагогічного колективу обговорюються на різних рівнях системи управління. Колегіальна діяльність органів управління орієнтована на розвиток самостійності та ініціативності членів цілісного педагогічного колективу. Разом 3 тим, функціональні обов'язки педагогів чітко визначені, є обов'язковими для виконання, відпрацьовані форми контролю та самоконтролю. Однак діяльність окремих педагогів в силу иi специфіки не може бути ефективною, якщо вона не узгоджена 3 діями інших педагогів, якщо немає єдності вимог в організації режиму дня навчального закладу, оцінки якості знань учнів та студентів.

Аналіз останніх досліджень та публікацій. Дослідженню даного питання сприяли праці Н. Руденко, Ф. Тейлора, С. Кузьміна, В. Новікова, К. Платонова , М. Барлінгейма, Р. Болуіса, Д. Гобкінза, Є. Маккі, Н. Вовкова, М. Молочко, Д. Паригін, Х. Шакуров, М. Обозова.

Мета статті. Для досягнення поставленої мети потрібно дослідити теоретичні основи формування соціально-психологічного клімату педагогічного колективу та запропонувати шляхи покращення соціально-психологічного клімату в педагогічіному колективі з метою удосконалення роботи підприємства.

Виклад основного матеріалу. У межах групових форм взаємодії людей їхні відносини поділяють на ділові, тобто офіційні (виникають стосовно спільної діяльності), та особистісні (грунтуються на почуттях симпатії й антипатіi); директивні, колегіальні й ліберальні (залежать від структурних особливостей організації); безпосередні (спілкування відбувається “обличчя до обличчя") або опосередковані певними засобами комунікації (лист, телеграф, радіо, телебачення); одномоментні й розгорнуті в часі (за часовою ознакою); об'єктивно задані (функціональні, субординаційні) й особистісні; емоційні, неопосередковані спільною діяльністю; міжособистісні, опосередковані цілями й змістом спільної діяльності; відносини взаємовідповідальності й залежності; приятельські, товариські стосунки; функціональні відносини по вертикалі та горизонталі: формальні й неформальні, ділові та особистісні, стабільні й ситуативні, кон'юнктивні й диз'юнктивні.

Зважаючи на різноплановість стосунків педагогів, учнів та студентів, А. Бойко класифікував їх за такими критеріями: 1) за метою і спрямованістю взаємодії: зовнішньо-спрямовані (формальні), диференційовано-спрямовані (неформальні), особистісно-спрямовані; 2) за змістом взаємодії: однобічнорепродуктивні, ситуативні, негативні; гармонійно-репродуктивні, обмеженоевристичні, позитивні; гармонійно-творчі, дослідницькі; 3) за способом взаємодії: вербально-інформаційні, інформаційно-практичні, вербально-організаційні; 4) за організацією взаємодії: фронтально-групові, диференційовано-колективні, індивідуально-колективні; 5) за семантикою взаємодії: оцінно-вольові, оціннорегулюючі, оцінно-стимулюючі; 6) за характером взаємодії: наступальні, офіційно-авторитарні, взаємнопоступливі й взаємновимогливі, шанобливовимогливі, дружньо-довірливі, взаємноуважні. Кожен тип характеризується 
такими рівнями виховуючих стосунків, як співпідпорядкування, співробітництво, співтворчість[4].

Взаємодія педагогів, залежно від того, наскільки вони дотримуються інтересів один одного, може розгортатися на таких засадах:

а) співробітництво — взаємодія, за якої педагоги сприяють задоволенню інтересів один одного, дотримуються приблизного паритету, об'єднують свої зусилля добровільно, спираючись на усвідомлення значення і необхідності розв'язання спільного завдання, на прагнення допомогти іншим учасникам спільної справи. Між ними виникають взаємні обов'язки і відповідальність;

б) суперництво - боротьба учасників взаємодії за реалізацію своїх інтересів, утвердження своєї позиції;

в) домінування - підкорення своїм інтересам партнера по взаємодії 3 використанням слабкості його позиції. Баланс інтересів за таких умов неможливий. Здебільшого домінування виникає внаслідок намагань однієї із сторін вибудувати взаємодію на свою користь, підпорядкувати собі іншу, яка намагається зберегти або відновити свій попередній статус. Якщо перевага однієї сторони стає явною, рівновага порушується, починається домінування.

У колективній діяльності важливо правильно планувати спільні дії, узгоджено виробляти, ухвалювати i реалізовувати рішення. їх ефективність залежить від гармонійності відносин у групі. У реальному бутті вони постають як система дій, за якої емоційний імпульс, вчинок однієї особи чи групи зумовлює відповідну реакцію інших осіб і виявляється як феномен "публічного ефекту" (зміна поведінки через вплив присутніх осіб).

Ступінь зв'язку між членами колективу залежить від особливостей взаємодії. За нетривалого взаємозв'язку більше можливості для самостійних дій, а зміцнення його підвищує значення керівних і координаційних функцій. 3 огляду на ступінь інтегрованості індивідів у групу розрізняють такі види взаємозв'язку: ізольованість (фізична й соціальна); уявний взаємозв'язок (існує у свідомості людини, стає реальним за потреби в спілкуванні); взаємозв'язок-присутність інших людей (зумовлений намаганням досягти публічного ефекту); вплив i взаємовплив (сприйняття, поведінка членів групи залежать від впливу, оцінок інших належних до неї осіб); справжній взаємозв'язок (дії одного члена групи неможливі без попередньої або одночасної дії інших).

Функціонально структуру колективу диференціюють на первинну (визначену умовами діяльності) і вторинну (розподіл рольових функцій у процесі безпосереднього розв'язання завдань залежно від комунікативних здібностей учасників). Зв'язок з оточенням здійснює лідер (керівник) колективу.

Спільну діяльність учасників усього колективу регулює мотивація сукупність психологічних чинників (система мотивів), які спонукають людину до певних учинків, поведінки, тобто іiі спрямованість і активність. За індивідуальної діяльності вона пов'язана з рівнем претензій і можливостей людини; за спільної діяльності претензії однієї особи можуть розходитися з прагненнями інших. Мотивація членів колективу залежить від умов діяльності, які можуть іiі послаблювати чи посилювати. Сила іiі залежить від ефективності взаємовпливу в 
колективі, спрямованість — від орієнтації на власний успіх (на себе), на групу (на інших), на діяльність (на розв'язання завдання). 3 розвитком взаємозв'язку посилюється мотивація членів колективу щодо ефективності спільної діяльності, інакше може виникнути конфлікт. На міжособистісні стосунки, ефективність спільної діяльності впливають й індивідуально-психологічні особливості (співвідношення темпераментів, інтелекту, характерів, інтересів тощо) членів колективу та рівень його однорідності (співвідношення поглядів, оцінок, ставлення до себе, партнерів, діяльності).

Також впливають на функціонування колективу подібність і розбіжності соціальних установок, які породжують симпатії чи антипатії між індивідами, обумовлюють рівень їх сумісності - ефекту від взаємодії людей, що означає максимальне суб'єктивне їх взаємне задоволення. Можлива вона за оптимального поєднання людських рис, що сприяє досягненню успіху в спільній діяльності. Існують такі види сумісності індивідів:

— фізична сумісність. Виявляється вона в гармонійному поєднанні фізичних якостей людей, без чого неможлива їхня продуктивна спільна діяльність;

- психофізіологічна сумісність. Основою іiі $\epsilon$ особливості роботи аналізаторної системи, темпераменту тощо (проблеми в спілкуванні виникають у людей 3 яскраво вираженими рисами холеричного або флегматичного темпераменту);

- соціально-ідеологічна сумісність. Ця сумісність стосується політичних, наукових, моральних, естетичних, філософських знань, умінь, навичок, особистісного, ціннісного ставлення до себе й інших.

На ефективність взаємодії впливають і біоритми людини. Іноді конфлікти у спілкуванні виникають у “сови” й “жайворонка”. Учитель (учень)-“сова”, як правило, зранку має знижену працездатність, пригнічений настрій, млявий, дратівливий, а тому може некоректно відреагувати на зауваження, які дещо пізніше сприйняв би зовсім інакше. “Жайворонок”, навпаки, утомлений, дратівливий у другій половині дня.

Основною ознакою сумісності є суб'єктивна задоволеність, адже основою будь-якого впливу людини на людину є взаємна залежність. Вступаючи в контакт iз іншими, людина не тільки почувається інакше, ніж наодинці, у неї по-іншому відбуваються і психічні процеси. Експерименти засвідчили, що присутність інших людей може полегшити чи ускладнити діяльність і поведінку індивіда. Навіть взаємодія двох осіб суттєво змінює їх. Взаємовплив, за спостереженням психологів, може реалізовуватися як взаємне полегшення (успішність діяльності кожного); однобічне полегшення (присутність одного полегшує діяльність іншого); взаємне утруднення (збільшення кількості помилок у діяльності кожного); однобічне утруднення (присутність одного може заважати діяльності іншого); незалежність (трапляється дуже рідко, означає, що присутність інших ніяк не позначається на діяльності кожного).

Якщо колектив досягає високих результатів у спільній діяльності за колосальних затрат психічної енергіі, нервових зривів, це дає підстави сумніватися у психологічній сумісності людей, які належать до нього. Загалом 
психологічну сумісність і успіх спільної діяльності зумовлюють оптимальні психофізіологічні якості кожного індивіда, критичне ставлення до себе й терпимість до інших, цілковита взаємодовіра тощо.

Педагогічний колектив - це суть самого навчального закладу, все ціле, що об'єднане з педагогічними загальними завданнями, які схожі між собою за віком, інтересами, педагогічними поглядами, інтелектом. Навчальний заклад це як вогнище вихованості і освіченості, сила моральної та ідейної дії впливу старших учнів та студентів на підростаюче покоління. Осердям педагогічного колективу $є$ єдність самих етичних цінностей, інтелектуального багатства, ну i також авторитету самого старшого покоління. Ця роль в єдності є вирішальною $\mathrm{i}$ належить моральним відносинам між педагогами в колективі, і між колективом учнів та студентів, і педагогічним колективом.

Специфіка педагогічної діяльності, яка визначається в етиці педагогічного колективу є тривалість і наступність праці, це потрібно для того, щоб виховати дитину. Крім цих особливостей потрібно ще й без кінця сіяти і без кінця пожинати плоди, адже пожинаючи плоди, ми і сіємо, а сіючи, пожинаємо їх. Це $\epsilon$ одною із головних засад етики відносин у педагогічному колективі. Деякі норми відносин псуються у колективі через те, що іноді вимушений він займатися ліквідацією, угрупуванням відставання, а ніж планомірною, нормальною роботою, щоб учні мали високі знання [4].

Можна сказати, що із важливих джерел педагогічної етики педагогічного колективу $є$ стійке переконання кожного педагога в тому, щоб працювати над вихованням людини потрібно насамперед думати.

Основним предметом роздумів в педагогічному колективі $\epsilon$ питання шкільного життя, яким саме повинна бути кожна особистість , 3 чим педагоги мають приходити в свій колектив, щоб навчальний заклад мав реальну виховну силу. Кожний колектив повинен бути твердо переконаний, щоб створення педагогічної етики це є передусім їхнє самовиховання. Безперервний, постійний самоаналіз, вміння вдосконалювати свою мудрість у вихованні, це є сенс злагоди у відносинах в педагогічному колективі.

Ще одна особливість в становленні етики в педагогічному колективі, яка полягає в тому, що до самого виховання причетні не тільки педагоги, учні, студенти та навчальний заклад, а людина, яка піддається цим впливам і має безліч найрізноманітніших дотиків. У педагогічному колективі взаємовідносини грунтуються на розумінні особливостей виховання, навчання і самовиховання в єдності, щоб взаємовідносини в педагогічному колективі були створенні на чесності, відповідальності, почутті обов'язку, гідності потрібно подбати перш за все, щоб усі педагоги мали одну думку в поглядах на дитину. Також в педагогічному колективі головною і найважливішою нормою відносин є вірність переконання. Життєрадісні, оптимістичні відносини у педагогів складається на грунті дитячої радості, дитячого щастя, творцями яких $\epsilon$ сам педагогічний колектив.

Законом із життя педагогічного колективу $є$ істина, в якій має бути дух обов'язку, працьовитості, тобто повинності, що панує в навчальному закладі, 
вимагає вимогливості як індивідуальну рису етики кожного педагога i взаєморозуміння в колективі. Вимогливість як до себе і як до інших, це є дитина працьовитості та обов'язку.

Суттю особистості педагога $\epsilon$ віра в людину, яка пропонує щоденні взаємовідносини в колективі за будь якої умови, педагоги щоденно заглиблюються у складнощі вихованця, його внутрішнього світу, осягають найважливішу людську i педагогічну мудрість уміння відчути i зрозуміти людину. Для того, щоб повірити в людину і співпадати думками в цій вірі, потрібно знати іiі. Дійсна віра в людину і реальна доброта основана важкою працею, великим напруженням сил, це напруження полягає в тому, що педагоги прагнуть глибше пізнати того, кого виховують.

Показниками позитивної соціально-психологічного стану у педагогічному колективі $\epsilon$ :

Організованість та згуртованість. Це значить, що успіх діяльності школи повинен забезпечувати колектив однодумців, у якому поважати творчі здібності, інтереси, характер.

Єдність неофіційної сфер спілкування та офіційної. Якщо ця ступень буде вища, то це краще та ефективніше впливатиме на педагогічні досягнення в цілях.

Чудовий настрій у колективі. Це залежить від сімейної злагоди, самопочуття, результатів своєї роботи і від зовнішніх умов. Стан колективної опіки в педагогічному колективі, підтримки та взаємоповаги.

Міжособистісними стосунками в педагогічному колективі, містять широкий діапазон явищ, що класифікуються з такими компонентами, а саме як розуміння й сприйняття людьми одне одного; поведінка та взаємовплив; міжособистісна привабливість. В групових формах взаємодії людей та їхні стосунки поділяють на особистісні, і ділові, а також директивні, ліберальні й колегіальні, вони повинні залежати від побудованих особливостей організації; безпосередні, це коли дві людини спілкують обличчям до обличчя, або опосередковані засоби комунікації ( телеграф, телебачення, радіо); емоційні та неопосередковані згуртованою діяльністю; міжособистісні цілі й змістом згуртованої діяльності; товариські стосунки; відносини залежності і взаємовідповідальності [5].

Міжособистісні конфлікти у педагогічному колективі

Найчастіше конфлікти в педагогічних колективах виникає під час порушення культурних, морально-етичних норм життя та інших норм.

Міжособистісний конфлікт — це ситуація між людьми, за яких вони мають дотримуватися несумісних норм та цінностей, вони намагаються реалізувати це у конкурентній боротьбі.

У спілкуванні розрізняють такі групи міжособистісних конфліктів:

конфлікти, які досягненні в цілях трудової діяльності; конфлікти, які в досягнених особистих цілях; конфлікти, які спричинені протидією людей соціальним нормам.

Педагогічні відносини є соціальним явищем і інтегрованим феноменом, який вміщує психологічні та філософські знання. у філософії вивчають соціальний, та об’єктивний аспект феномена, а у психології - суб'єктивний. педагогіка 
комплексна наука і вона об'єднує їх, і досліджує відносини двох суб'єктів на економічному, національно-культурному тлі.

Взаємовідносини між педагогами як членами працьовитого колективу, вихователів, між педагогами 3 одної сторони стають вихованцями, а 3 іншої сторони вони стають царством працьовитості, вимогливості та обов'язку лише за однієї умови, якщо працьовитість проникає в думки педагога, в його творчі та інтелектуальні інтереси.

\section{Взаємовідносини педагога з учнями}

Педагог та учень $є$ одним із розгорнутих відношень в навчальному процесі. Тут встановлюється різні механізми виховання та передавання творчих здібностей, перетворюючого та пізнавального досвіду діяння. Педагог - це розкрита, жива скарбниця винахідництва, думки, професіоналізму, оригінальний досвід педагога та високий фах, це $\epsilon$ першою умовою контактів з учнями. Головною метою учнів та студентів $\epsilon$, засвоєння перетворюючих образів та пізнавальних актів творіння педагога, стати успішним, продуктивним та оригінальним. Головним завданням педагога - $\epsilon$ навчити учнів та студентів самостійно сприймати і вирішувати свої проблеми.

Відносини між учнем та вчителем повинні бути дружніми та не варто забувати про авторитет педагога перед учнем.

Щоб знайти індивідуальний підхід до кожної дитини потрібний хист, та нажаль, не кожний педагог ним володіє. Діти дуже емоційно сприймають увагу педагога, і тому із перших днів ясно - хто для педагога потрапляє до лав улюбленців, а хто так і залишається сірою масою. Це добре, якщо педагог дозволяє задавати запитання під час уроку, терпляче відповідає на них, допомагає дітям.

Дитина запам'ятовує педагога як позитивного персонажа, тому не боїться відповідати на уроці та бути активною на перерві. Але, у педагогів також буває поганий настрій. Існує, що педагог тільки відповів на питання, чи звернувся до дитини 3 невластивою йому інтонацією, а дитину це розгубило, оскільки така інтонація видалась їй грубою.

Головне у роботі педагога — встановити довірливі і шанобливі відносини 3 учнем. Це дає можливість передавати знання у спілкуванні. Для педагога важливі не тільки теоретичні знання, а й вміння побачити в дитині особистість, індивідуальність, щось, що властиве лише цій дитині та сприяти розвитку його здібностей, уваги, творчості, знань, умінь, навичок. Вчити навчатися самому. Викладачі усіх предметів, i насамперед соціології, мають дати учням основні поняття і судження, а учні уже самостійно розвиватися в тому або іншому напрямі. У цьому дітям допоможе робота над собою, саморозвиток.

Висновки. Вивчаючи, досліджуючи людину, педагоги навчаються, виробляти в своєму колективі найбільш важливе переконання, що визначає етику їхніх взаємовідносин. В своїх вихованцях педагоги бачать віддзеркалення свого розуму, допитливості, любові до науки, прагнення до знань. Педагоги переконуються, що учень може стати вихованцем тільки тоді, коли для зразку в нього $є$ певна особистість, яка $€$ його натхненником, захопленням i просто 
ідеальна. Педагогічний колектив цінить переконання, що виникало протягом десяти років про мудрість виховання. Якщо немає цієї віри, то і немає виховання.

Педагогічна праця з першого погляду здається нудною та одноманітною, але це $\epsilon$ не так. Радість і творчість праці, знаходиться у постійному пізнанні, відкритті, осягненні, у захопленні перед усім новому й новими людськими таємницями, які ніколи не закриваються перед душею людства.

Щоб завжди радіти, відкривати, захоплюватися, потрібно жити не покидаючи думок про вірну, вічну працю.

\section{Лimepamypa:}

1. Митина Л.М. Психология труда и профессионального развития учителя: учебное пособие / Л.М. Митина. - Москва : Академия, 2004.- 320 с.

2. Реан А. А., Коломинский Я. Л. Социальная педагогическая психология - СПб.: Издательство «Питер», 2000. -416 с.

3. Психологический словарь /Под общ. ред. А. В. Петровского, М. Г. Ярошевского. - 2-е изд., испр. и доп. - Москва:1990. - 494 с.

4. Бойко А. М. Виховання людини: нове і вічне : методолого-теоретичний і практичний коментар: статті, виступи, рецензії / Алла Бойко. - Полтава : [Техсервис], 2006. - 568 с.

5. Альохіна О. Е. Стимулювання розвитку працівників організації / О. Е. Альохіна // Управління персоналом. - 2002. - № 1. - с. 50-52.

6. Прокопенко І. Ф. Педагогіка та психологія : збірник наукових праць / під ред. I. Ф. Прокопенко - К.- 2011 - 230 с.

\section{References:}

1. Mitina, L.M. (2004). Psihologija truda i professional'nogo razvitija uchitelja [Psychology of labor and professional development of a teacher]. Moscow: Akademija [in Russian].

2. Rean, A.A. \& Kolominskiy, Ya. L. (2000). Social'naja pedagogicheskaja psihologija [Social pedagogical psychology]. Moscow: Izdatel'stvo «Piter» [in Russian].

3. Petrovsky, A. V. Yaroshevsky, M. G.(1990). Psihologicheskij slovar' [Psychological Dictionary]. Moscow: Akademija [in Russian].

4. Boyko, A.M. (2006). Vihovannja ljudini: nove i vichne [Human education: new and eternal]. Poltava: Techservice [in Ukrainian].

5. Alyokhina, O.E. (2002). Stimuljuvannja rozvitku pracivnikiv organizaciï [Stimulating the development of employees of the organization]. Upravlinnja personalom - Personnel Management, 1 , 50-52 [in Ukrainian].

6. Prokopenko, I. F. (2011) Pedagogika ta psihologija [Pedagogy and psychology]. Kiev [in Ukrainian]. 